July 1999 • NREL/TP-520-26490

\title{
Solar Technology and the Insurance Industry: Issues and Applications
}

A. Deering and J.P. Thornton

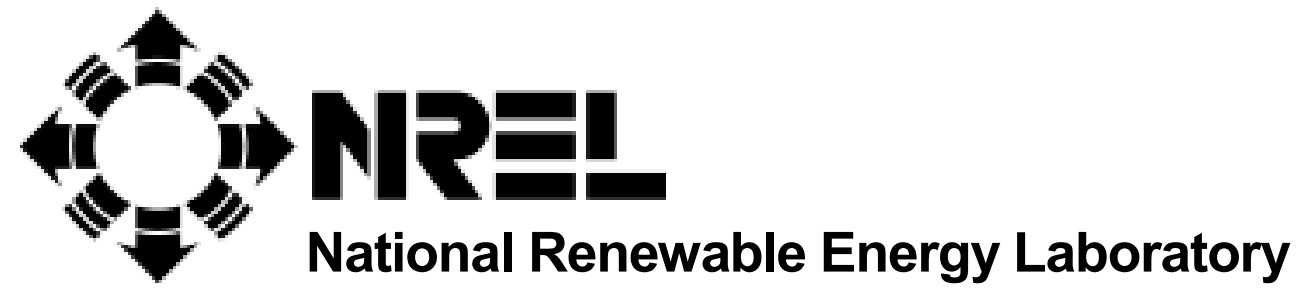

1617 Cole Boulevard

Golden, Colorado 80401-3393

NREL is a U.S. Department of Energy Laboratory

Operated by Midwest Research Institute $\bullet$ Battelle $\bullet$ Bechtel

Contract No. DE-AC36-98-G010337 
July 1999 • NREL/TP-520-26490

\section{Solar Technology and the Insurance Industry: Issues and Applications}

\section{A. Deering and J.P. Thornton}

Prepared under Task No. PV908101

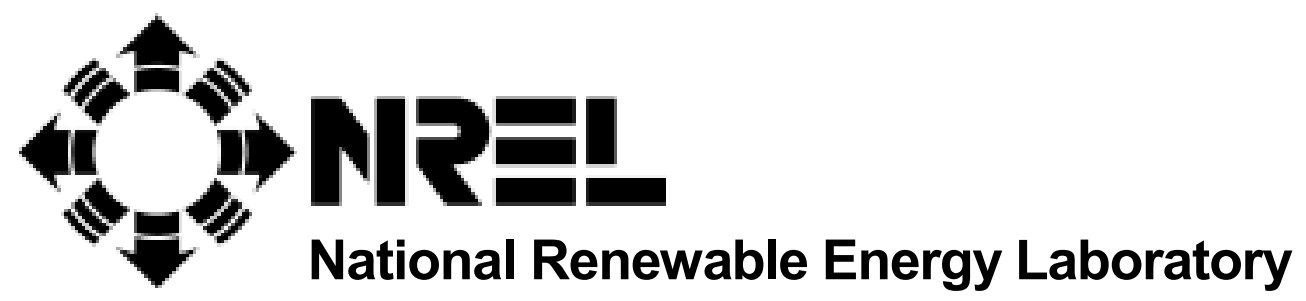

1617 Cole Boulevard

Golden, Colorado 80401-3393

NREL is a U.S. Department of Energy Laboratory

Operated by Midwest Research Institute • Battelle • Bechtel

Contract No. DE-AC36-98-G010337 


\section{NOTICE}

This report was prepared as an account of work sponsored by an agency of the United States government. Neither the United States government nor any agency thereof, nor any of their employees, makes any warranty, express or implied, or assumes any legal liability or responsibility for the accuracy, completeness, or usefulness of any information, apparatus, product, or process disclosed, or represents that its use would not infringe privately owned rights. Reference herein to any specific commercial product, process, or service by trade name, trademark, manufacturer, or otherwise does not necessarily constitute or imply its endorsement, recommendation, or favoring by the United States government or any agency thereof. The views and opinions of authors expressed herein do not necessarily state or reflect those of the United States government or any agency thereof.

Available to DOE and DOE contractors from:

Office of Scientific and Technical Information (OSTI)

P.O. Box 62

Oak Ridge, TN 37831

Prices available by calling 423-576-8401

Available to the public from:

National Technical Information Service (NTIS)

U.S. Department of Commerce

5285 Port Royal Road

Springfield, VA 22161

$703-605-6000$ or $800-553-6847$

or

DOE Information Bridge

http://www.doe.gov/bridge/home.html

Printed on paper containing at least $50 \%$ wastepaper, including $20 \%$ postconsumer waste 


\section{TABLE OF CONTENTS}

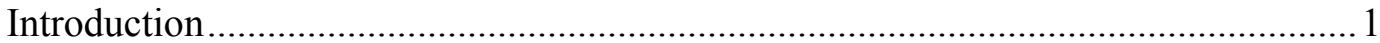

The Problems with Disasters - They Really Happen....................................................2

Power Outages_-Roadblocks to Recovery..................................................... 4

Portable Gasoline Generators-Accidents Waiting to Happen........................ 5

Business Interruption Losses - a Double Whammy..........................................5

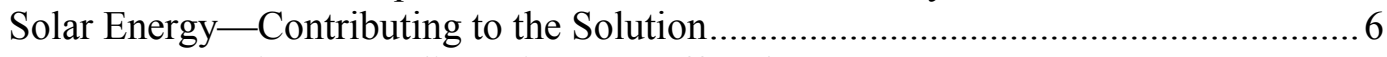

Prevention - Heading Disasters Off at the Pass ............................................ 7

"Green Buildings and Solar Energy"-A Better Chance of Survival ............... 8

Aftermath-Power from the Sun.............................................................. 11

Solar Technologies - Added Value to Consumer and Insurer Alike ............. 11

Next Steps

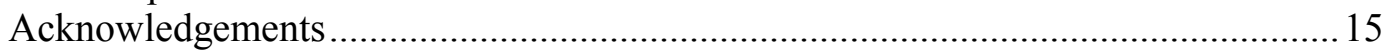

\section{LIST OF FIGURES}

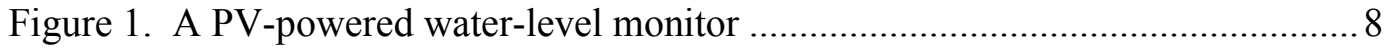

Figure 2. Mobile PV-powered highway advisory radio system................................ 8

Figure 3. Vacation cabin on Island of St. John, Virgin Islands .................................. 9

Figure 4. Before and after photos of a PV streetlight in a Miami suburb ................... 10

Figure 5. Portable PV genset helicoptered into California mountains........................ 11

Figure 6. Mobile communications and lighting unit............................................. 12 


\title{
Solar Technology and the Insurance Industry: Issues and Applications
}

\author{
Ann Deering, Consultant \\ and \\ John P. Thornton, P.E. \\ National Center for Photovoltaics \\ National Renewable Energy Laboratory
}

\section{Introduction}

Today's insurance industry strongly emphasizes developing cost-effective hazard mitigation programs, increasing and retaining commercial and residential customers through better service, educating customers on their exposure and vulnerabilities to natural disasters, collaborating with government agencies and emergency management organizations, and exploring the use of new technologies to reduce the financial impact of disasters.

According to William J. Poutsiaka, President and Chief Executive Officer of Arkwright Mutual Insurance Company, "We know enough about the risks, however, to aggressively promote programs that prevent, mitigate, and control losses caused by natural disasters. This is the time to invest resources in prudent risk avoidance, to protect ourselves and our economy against the whims of Mother Nature - today, tomorrow, and for years to come. At the very least, improvements in early-warning systems, strategic planning, and disaster response are pragmatic measures that can be pursued by business and industry working closely together with communities and government."

In June of 1998, the National Renewable Energy Laboratory (NREL) and the National Association of Independent Insurers (NAII) sponsored a seminar titled, "Solar Technology and the Insurance Industry." Presentations were made by insurance company representatives, insurance trade groups, government and state emergency management organizations, and technology specialists.

The meeting was attended by insurers, brokers, emergency managers, and consultants from more than 25 U.S. companies. Leading insurers from the personal line and commercial carriers were shown how solar technology can be used in underwriting, claims, catastrophe response, loss control, and risk management. Attendees requested a follow-up report on solar technology, cost, and applications in disasters, including suggestions on how to collaborate with the utility industry and how to develop educational programs for business and consumers.

This report will address the above issues, with a emphasis on pre-disaster planning and mitigation alternatives. It will also discuss how energy efficiency and renewable technologies can contribute to reducing insurance losses. 


\section{The Problem with Disasters — They Really Happen}

Catastrophes are now part of everyday life. They impact every region of the United States, are increasing in terms of frequency and severity, and result in significant property damage and economic losses. Fifty percent of all property losses over the last 40 years have occurred since 1990, and 21 of the 24 largest insured weather-related disasters have also occurred in the last decade.

Over the five years from 1986 to 1991 , major disasters cost the federal government $\$ 3.3$ billion in aid to individuals and local governments. During the next five years (1991 to 1996), federal aid quadrupled to more than $\$ 13$ billion. ${ }^{1}$ As massive as this federal assistance sounds, it represents only part of the losses; the insurance sector picked up billions more in payments to both individuals and commercial enterprises. The insurance industry has become the hardest hit of all commercial sectors by disasters. According to the Property Claims Service, insurers have paid over \$89 billion in catastrophe losses between 1989 and 1998.

The total 1993 value of all commercial structures in the United States was \$11 trillion, representing a $65 \%$ increase over 1988. According to the Insurance Institute for Property Loss Reduction (now the Institute for Business and Home Safety), insured coastal values increased $69 \%$ during this time, from $\$ 1.86$ trillion in 1988 to $\$ 3.15$ trillion in 1993 , or about $15 \%$ of the total for all of the United States in counties within 50 miles of the coast. During this time period, the value of residential exposures increased $75 \%$, while commercial exposures increased $63 \%$.

As people continue to gravitate to the coast to settle, the property values of homes and commercial structures will also grow, steadily increasing the insurance industry's exposure to natural disasters. Florida and New York have the largest exposures, with the 1993 Florida figure of $\$ 871.7$ billion expecting to increase to over $\$ 1$ trillion. New York's coastal exposure doubled from $\$ 301.7$ billion in 1988 to $\$ 595.6$ billion in 1993. Long Island's exposure alone exceeds $\$ 550$ billion.

A recent study led by the U.S. Army Corps of Engineers determined the vulnerability of New York City's transportation system to hurricanes. The analysis indicated that if a Category 3 storm, like the one that struck Long Island in 1941, were to strike Manhattan today, water surging through the streets would flood all subway and rail stations, all tunnels, and leave "slosh" marks as high as 30 feet on the World Trade Center.

Hurricane Andrew in 1992, the most destructive natural disaster in U.S. history, resulted in a total economic loss of $\$ 25$ billion, of which insurance companies covered some 680,000 claims exceeding $\$ 16$ billion. If Andrew had struck just 15 miles further inland, the insured losses might have reached an estimated $\$ 65$ billion. $^{2}$ Projected insured losses from a similar Category 4

\footnotetext{
${ }^{1}$ Witt, James Lee, “Creating the Disaster-Resistant Community," American City and County, Intertec Publishing Corporation, Overland Park, Kansas, January 1997.

2 Based on lost property-tax revenues; this estimate does not include human relocation and medical costs, business losses, etc.
} 
hurricane striking New York City ranged as high as $\$ 45$ billion. Long Island could have accounted for another $\$ 40$ billion.

This possibility is further supported by studies conducted by the insurance industry. Peter Kelly, Vice President, Applied Underwriting Research, Arkwright Mutual Insurance, and Dr. Lixin Zeng, Vice President, E.W. Blanch Co., a Minneapolis-based consulting firm, used a natural disaster computer model to develop hurricane damage estimates in their 1998 study: "The Temporal and Spatial Variability of Economic Losses Due to Intense Hurricanes: A Comparative Analysis." Kelly and Zeng state that, although it is well known that southern Florida is expected to face the most frequent and most severe hurricanes, the northern Atlantic coast faces the potential for infrequent, but devastating, hurricanes. Intense hurricanes making landfall could cause $\$ 100$ billion or more in damage in New England, New York/New Jersey, and Florida. A major event around Virginia and Maryland could cause $\$ 70$ billion in damage, and one in Texas or Louisiana could cause more than $\$ 50$ billion in damage.

And there is no end in sight to the onslaught of hurricanes, tornadoes, wind storms, ice storms, fires, and floods. In the first three quarters of 1998 alone, there have been 36 insurance catastrophes $^{3}$ with losses exceeding \$6 billion—-twice the total 1997 figure of \$3.1 billion.

Thousands of people are trying to resume their lives in the aftermath of Hurricane Georges. More than 685,000 claims are expected to be filed from policyholders. The total insured loss is estimated to be $\$ 1.7$ billion in Puerto Rico alone, according to the Insurance Services Office Property Claim Service. Additionally, the hurricane caused widespread damage to the U.S. Virgin Islands (\$50 million), Florida (\$325 million), Mississippi (\$310 million), Alabama (\$100 million), and Louisiana (\$15 million).

And perhaps nature has even greater surprises in store. Deep beneath the earth's surface in the Mississippi Valley lies the New Madrid ${ }^{4}$ Fault. The fault is named after a small town in southeastern Missouri that was devastated in 1811-12 during the worst series of earthquakes this country has ever experienced. Registering up to 8.7 on the Richter scale, these quakes affected up to 600,000 square miles. ${ }^{5}$ Today, a quake of similar magnitude would affect more than a quarter of the U.S. population, with estimated property losses of $\$ 500$ billion or more.

According to many geologists and emergency management experts, New Madrid "is a time bomb waiting to happen.",6

It is obvious that no single industry sector can afford to absorb losses of this magnitude. Although insurers are taking proactive steps to reduce further losses, it is obvious that full

${ }^{3}$ A catastrophe is defined as an event that causes $\$ 25$ million or more in insured property losses and affects a significant number of property and casualty policyholders and insurers.

4 The first syllable is pronounced "mad."

5 To provide a comparison, the 1906 San Francisco earthquake registered 8.3 on the Richter scale and affected only 40,000 square miles.

6 Star, Jack, Chicago magazine, November 1984, pp. 180-185, 251-253. 
recovery from catastrophes such as these will require a partnership of private and public sectors to plan for and respond to disaster situations.

\section{Power Outages — Roadblocks to Recovery}

It seems that only when disaster strikes do we realize the extent to which we rely on electrical power. Cooking, refrigeration, furnace operation, the pumping of gasoline, and even the recharging of laptop computers and cellular phones all require electricity. It is almost axiomatic that when a serious disaster strikes, local utility power disappears at least temporarily. ${ }^{7}$

Because of our highly centralized society, even small disasters have the potential to affect large regions. On July 2, 1996, a sagging utility line in Oregon triggered a fire in a nearby pine tree. The fire in turn burned a utility pole, which disrupted local service and touched off a chain reaction, creating power outages that eventually affected two million people in 14 western states and part of Canada. Six weeks later, on August 10, another sagging utility line disrupted power to six million people in ten states. ${ }^{8}$

Hurricane Andrew, striking the suburbs of Miami in August 1992, left about 3 million homes and businesses without power, including 1.4 million Florida Power and Light (FP\&L) customers. About 5,000 traffic signals were damaged, some 21,100 utility poles were downed, and 26,158 street lights were blown out. Several hundred thousand people lost their homes.

Water and wastewater utilities were also hit hard, as felled trees broke water mains and distribution lines and as power outages disabled pumps. FP\&L customers in the northern part of Dade County (Miami area) had electricity again within two weeks, but power in the devastated southern section was out for at least a month—in some cases, much longer.

Most homeowners relied on portable gasoline-powered generators to keep their refrigerators running and perhaps to operate a light and a small fan for a few hours each night. A "boil water" advisory was in effect, but only those with gas grills and enough fuel could comply. Most people were forced to rely on imported water.

The Northridge Earthquake provides yet another example of the importance of power. Shaking Southern California on January 17, 1994, the earthquake caused widespread power outages throughout the area and beyond, though most of them were not prolonged. The entire Los Angeles Department of Water and Power (LADWP) utility system went down, leaving 1.3 million customers without electricity. Working around the clock, LADWP restored power to half of the customers within six hours, and 95 percent of their customers had power again within 24 hours.

\footnotetext{
7 “Masters of Disaster, Recent Catastrophes Are Testing Insurers' Mobile-Computing Mettle," Insurance and Technology, August 1998.

${ }^{8}$ USA Today, Monday, August 12, 1996, NEWS Section, page 1A.
} 
Another utility, Southern California Edison, lost 1.1 million of its 4.2 million customers, but had power restored to 800,000 of them within a few hours. Almost all Edison customers regained electricity within a few days.

Despite the utilities' dedicated efforts to restore power, close to 100,000 homes and businesses were without electricity for more than 24 hours. Natural gas leaks kept power from being restored in many of the affected areas. Power was available but could not be turned on for fear that sparks would touch off fires. About 100 gas-related fires did erupt, a number of which involved premature restoration of electric power. Any source of electricity would pose similar risks, so even renewable back-up systems would have to be shut down in areas without power due to gas leaks.

\section{Portable Gasoline Generators - Accidents Waiting to Happen}

Portable generators are commonly used following disasters to provide electricity to both businesses and residences. About $95 \%$ of these generators are powered by gasoline, with most of the remainder using propane. Although gasoline-powered generators can provide power, they are not without their safety problems. Local newspapers are often filled with post-disaster accounts of burns, fuel explosions, and asphyxiations associated with homeowner use of small generators. Local responders also complain that the noise from gasoline or diesel generators is annoying and adds to the trauma of already fragile victims.

The following quote, from a report from the Strom Thurmond Institute, describes the application of generators after Hurricane Hugo in 1989: "Emergency generators are the most important pieces of equipment used during the restoration process, but careful planning is needed to ensure their availability and safe operation. All sizes of generators proved invaluable for maintaining health, safety, and security operations. Especially in rural communities, the value of portable sources of power to operate small retail facilities to provide milk, ice, food, gasoline, and the like cannot be overestimated." 9

The insurance industry does not track the statistics on the use of portable generators after disasters or on the accidents resulting from them. Generators are usually provided by insurers under the Additional Living Expense portion of a typical homeowners policy. About 85\%-90\% of insureds are eligible for generators under homeowner policies.

\section{Business Interruption Losses - A Double Whammy}

Power outages often have a catastrophic effect on business. In February of 1998, a power failure occurred in Auckland, New Zealand, when four underground cables from a nearby hydroelectric plant failed due to searing heat and overload; nearly 2,000 businesses were affected in downtown Auckland. At the time of the report, power had already been out for 13 days. Some businesses were expected to be without power for five to ten weeks. Merchants estimated that they were

\footnotetext{
9 “Hurricane Hugo: Lessons Learned in Energy Emergency Preparedness," Strom Thurmond Institute, 1990.
} 
losing \$60 million a week as a result. Some faced bankruptcy. Business owners were being urged to sue their insurers, the local utility, and the City of Auckland. ${ }^{10}$

The April 1997 floods in North Dakota resulted in \$1 billion in business property and inventory losses - about $6 \%$ of the state's annual gross product. The floods highlighted a major problem: small businesses are often under-insured, or even uninsured, and many do not recover following a major disaster. In this case, fewer than $10 \%$ of the damaged properties were insured. Business equity was reduced by more than $\$ 400$ million. As of May 1998, 150 businesses had not reopened; those that did reopen reported substantially higher levels of debt. ${ }^{11}$

Power outages impact large and small businesses alike. According to a 1998 survey of 500 small business owners, which was sponsored by Allied Signal Power Systems Inc., small businesses reported an average of three power outages during the past year, costing each business about $\$ 7,500$ per day on average.

"Because today's businesses are increasingly reliant on electronic equipment, the importance of reliable electric power is essential," says Tony Prophet, President and CEO of Allied Signal Power Systems. "But it is difficult to quantify the effect of a power outage. While businesses can calculate the average loss for such things as spoiled food, perishables, or lost sales, it isn't always easy to assign a dollar value to the intangibles - items like lost productivity, lost customers, and lost computer data."

According to the survey's results, uninterrupted, reasonably priced power was "very important" to $93 \%$ of the respondents. Of those surveyed, $80 \%$ attributed power outages to storms and lightning, whereas more than $50 \%$ blamed at least one of their power outages on problems at their power company.

Problems are compounded when outages follow a disaster. Businesses vital to recovery, such as service stations, hardware stores, grocery stores, and banks, often find themselves without power. Gasoline cannot be pumped from underground tanks without electricity, so both public and private transportation is severely affected. Not only are rescue operations hindered, but workers cannot get to their jobs, further slowing economic recovery.

Larger companies are also highly dependent on electrical power for continued operation. In the aftermath of the Northridge earthquake, many companies were forced to relocate to other cities, or even out-of-state, taking valuable jobs, revenues, and property taxes with them. Communities face the "double whammy" of trying to rebuild while holding on to their economic base.

\section{Solar Energy — Contributing to the Solution}

Renewables are viable, affordable and safe energy-generating technologies that can increase resilience and can help to respond and recover from disasters. Electricity from wind and

10 The Nando Times News, Nando Media, Raleigh, North Carolina, March 5, 1998.

${ }^{11}$ Lemarre, Leslie, "When Disaster Strikes," EPRI Journal, September/October 1988, pp. 8-16. 
photovoltaic (PV) cells can power communications, water purification, refrigeration, water pumping, medical equipment, and lighting. PV can be used to replace portable diesel and gasoline generators, power mobile catastrophe offices for insurers, and reduce reliance on fuel sources that can be expensive and scarce following a major disaster. Solar heating systems can also provide two other precious commodities: space heating for buildings and hot water for medical clinics and industrial processes.

Technologies such as PV and solar hot water only achieve their maximum effectiveness in buildings when combined with energy-efficiency measures. Energy-efficient buildings and appliances reduce the need for utility power. Daylighting not only improves the living environment, it also reduces the lighting load. When energy efficiency, passive solar, and daylighting are combined with solar systems to generate electricity and hot water, partial or even full operation can be maintained when traditional utility services disappear. ${ }^{12,13}$

The costs of solar systems have decreased dramatically in the past few years. Passive solar features, such as daylighting and energy-efficient lighting and appliances, can often be installed in a new building or retrofitted into an existing building at little or no extra cost. Solar hot-water systems are cost-effective in many areas of the United States, especially if added during new construction.

PV-generated energy, costing from 20 to 40 cents per kilowatt-hour, seems expensive at first when compared with the local utility. But what is the value of electricity during an emergency? The costs of PV compare favorably to those associated with operating and maintaining portable fossil-fueled generators, especially if the transportation of diesel fuel or gasoline is considered. When used for remote applications, such as weather stations, communication systems, and early warning devices, $\mathrm{PV}$ is often the least expensive option and far more reliable than the grid. ${ }^{14,15,16}$

\section{Prevention - Heading Disasters Off at the Pass}

Photovoltaics has proven itself through the years as a reliable and cost-effective source of power for remote applications. These attributes make it ideal to supply power for weather stations, airquality monitors, emergency communications, traffic control and evacuation operations, and early-warning systems of all types (Figures 1 and 2). ${ }^{17,18}$

12 "When Disaster Strikes, the Sun Can Still Shine Through," DOE/CH10093-282, National Renewable Energy Laboratory, March 1994.

13 "Nature's Power on Demand: Renewable Energy Systems as Emergency Power Sources," Office of Energy Efficiency and Renewable Energy, U.S. Department of Energy, October 1995.

14 Thornton, John P., "The Economics of Photovoltaics versus Line Extensions: Selected Case Studies," Proceedings of Solar '94, American Solar Energy Society, Boulder, CO, 1994, pp. 102-105.

15 Thornton, John P., "The Economics of Photovoltaics in Municipalities," Proceedings of Solar '96, American Solar Energy Society, Boulder, CO, 1996, pp. 347-351.

${ }^{16}$ Photovoltaics for Municipal Planners, TP-411-5450, National Renewable Energy Laboratory, April 1993.

${ }^{17}$ Ironically, the earliest application of PV (known by the authors) being used for insurance purposes occurred in the 1970s when Lloyd's of London required all North Sea oil drilling platforms to install PV backup 


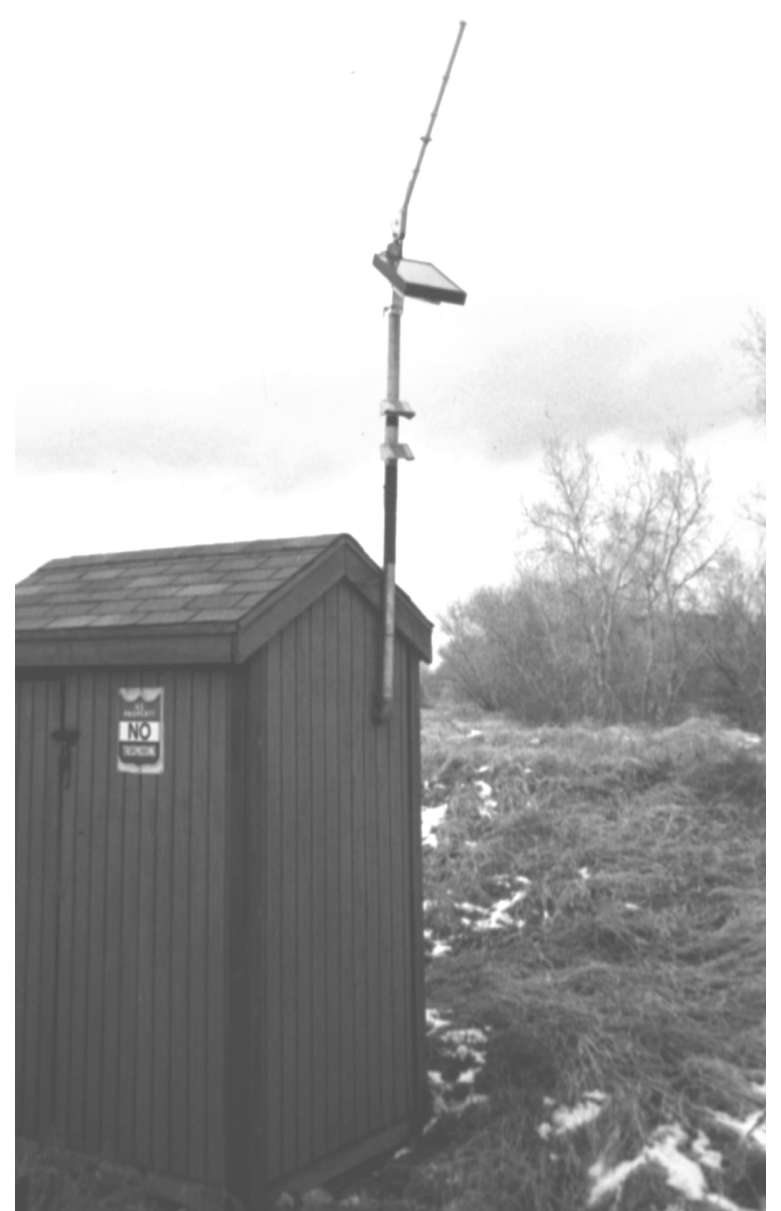

Figure 1. A PV-powered water-level monitor protects the City of Ft. Collins, Colorado, from floods by continually monitoring stream flow and radioing data to the city center. Alarms are triggered if the stream rises to dangerous levels, and emergency response procedures are started (photo by John Thornton, NREL).

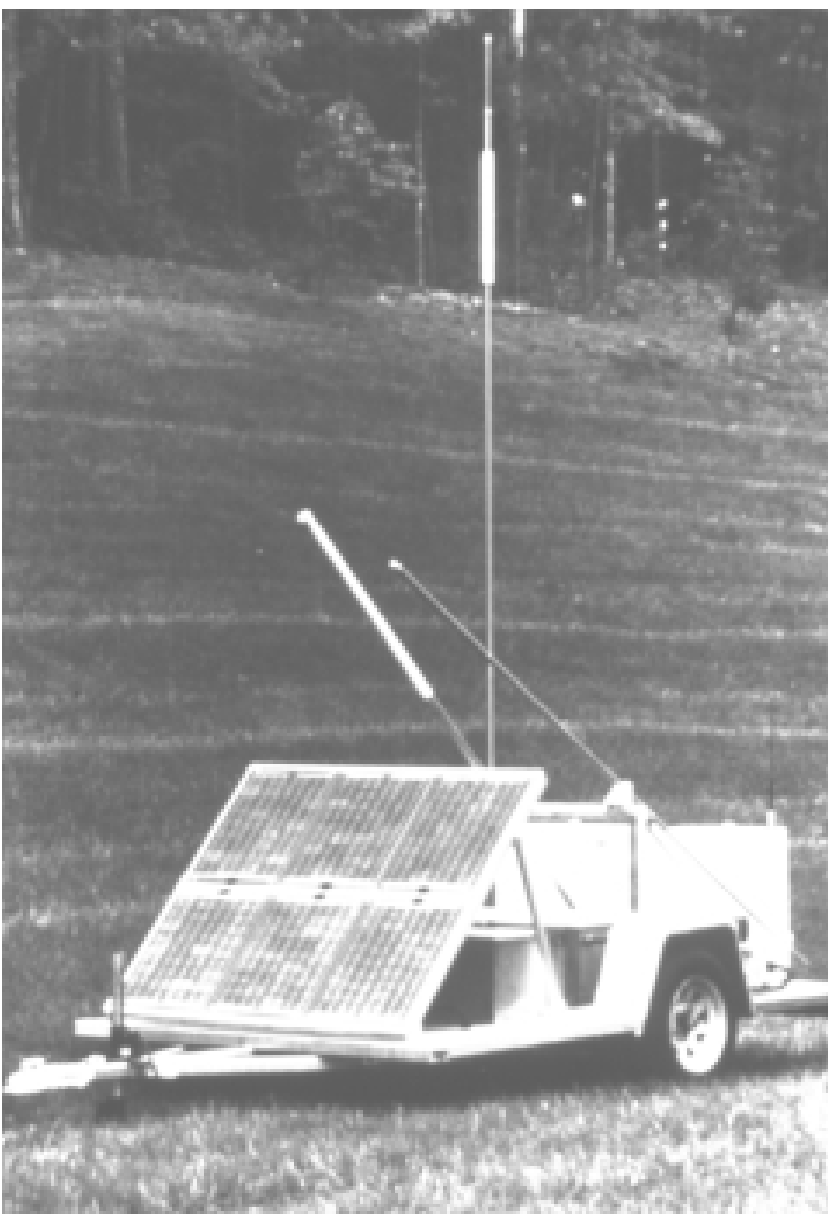

Figure 2. This mobile PV-powered highway advisory radio system was used to transmit weather information and route changes after Hurricane Andrew (photo courtesy of Digital Recorders).

\section{“Green Buildings and Solar Energy" —A Better Chance of Survival}

More than 80 percent of the structures destroyed during Hurricane Andrew were not built to established building codes. If building inspectors had enforced existing codes, property loss would have been substantially reduced. Furthermore, by taking advantage of the inherent strength of buildings incorporating energy efficiency and passive solar - as well as properly installed solar hot water and electric generating systems-disaster resistance could have been increased even further, resulting in lower property loss.

power for emergency communications as a condition for obtaining insurance.

18 Young, Jr., William R.; and Joe Schmidt, "PV Powering a Weather Station for Severe Weather," FSECPF-317-97, Florida Solar Energy Center, Cocoa, FL, 1997. 
Well-designed, energy-efficient buildings help maintain the quality of life during normal times. Natural daylight and proper air exchange have been shown to have many beneficial effects, including reducing diseases such as the common cold. Energy-efficient buildings also protect their inhabitants from temperature extremes, providing not only a safer environment, but also reducing their dependence on utility services. ${ }^{19,20}$

Solar hot-water systems and photovoltaic modules are designed to withstand severe environments. PV modules are designed to withstand one-inch-diameter ice balls moving at 23 meters per second (52 miles per hour). ${ }^{21,22}$ For maximum survivability, however, solar systems must be attached properly to underlying roof structures using simple but effective techniques that have proven themselves through the years. An excellent example of the survivability of both PV and solar hot-water systems is provided by the Harmony Resort on the

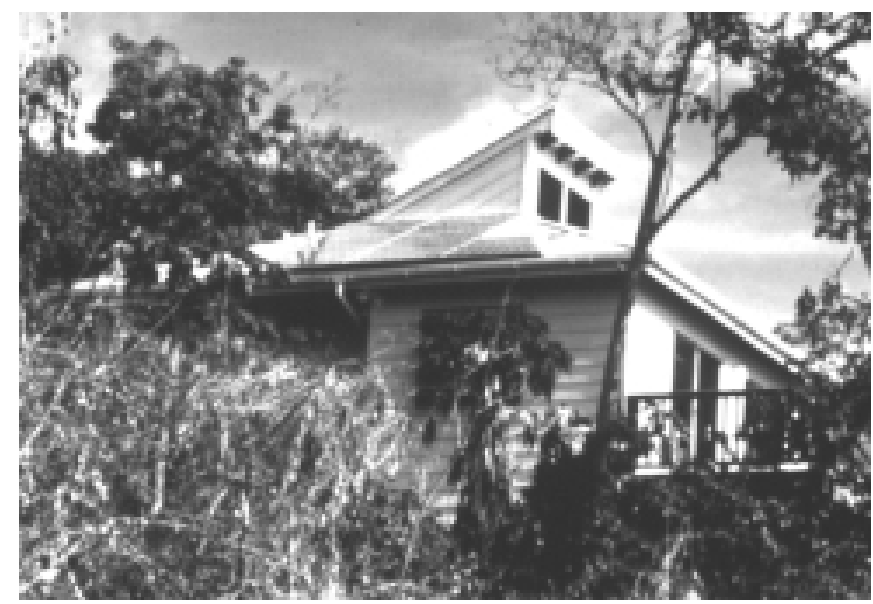

Figure 3. One of the vacation cabins at Harmony Resort on the Island of St. John in the Virgin Islands. The PV unit, which survived Hurricane Marilyn without damage, can be seen on the roof (photo by John Thornton, NREL). island of St. John in the U.S.Virgin Islands. The resort, designed on sustainable principles, is constructed entirely of recycled materials and uses both solar electric (PV) and solar hotwater systems (Figure 3). The resort survived both Hurricane Marilyn and Hurricane Georges with minimal damage and no loss of power, continuing to provide lights, communications, refrigeration, and hot water. Elsewhere on St. John, as well as on other nearby Caribbean islands, utility services were disrupted for weeks, and in some cases, for months.

Jim and Janice Cahill's energy-efficient solar home in Falmouth, Massachusetts, provides yet another example. Theirs was the only home for miles around that still had electricity when Hurricane Edouard ravaged Cape Cod on Labor

19 Judkoff, R; J. Thornton; N. Strawn; C. Gay; and P. Torcellini, "Disaster! Reduce the Risk of Insurance Loss with Renewable Energy Technologies," NREL/BR-330-22820, National Renewable Energy Laboratory, Golden, CO, May 1998.

${ }^{20}$ Mills, Evan; Ann Deering; and Edward Vine, "Energy Efficiency: Proactive Strategies for Risk Managers," Risk Management, Risk Management and Insurance Management Society, March 1998, pp. 12-16.

21 “IEEE Recommended Practice for Qualification of Photovoltaic (PV) Modules," IEEE Std 1262-1995, Institute of Electrical and Electronic Engineers, Inc., New York, NY, 1996.

22 One of the authors can personally testify that his solar hot-water system survived two-inch, egg-sized hail unharmed, while all the cedar shakes on his roof were destroyed during a summer hailstorm. 
PV does not have to be mounted on buildings to be survivable. During Hurricane Andrew, several suburbs of Miami were ravaged and left without any utility power. Yet, PV-powered streetlights in these suburbs not only survived, but were the only lights left operating for several weeks (Figure 4).

Mona Island, a wildlife refuge located $80 \mathrm{~km}$ (50 miles) west of the main island of Puerto Rico, has seven PV systems that replace noisy diesel and gasoline-powered generators. ${ }^{24}$ NREL staff checked out five of the systems immediately following Hurricane Georges in September 1998. Four of these systems survived without harm. In the immediate area surrounding one of the unharmed systems, all of the trees had been uprooted or blown away. The fifth PV installation suffered some damage from improper stowing, and also, because a waterspout reportedly hovered directly over the roof on which the system was mounted!

An important lesson is provided by one of the PV installations that survived unharmed, but was rendered inoperable because the power line that connected the system to its load was destroyed. Because power lines are very vulnerable to natural disasters, PV is most effective when used as close as possible to the load.
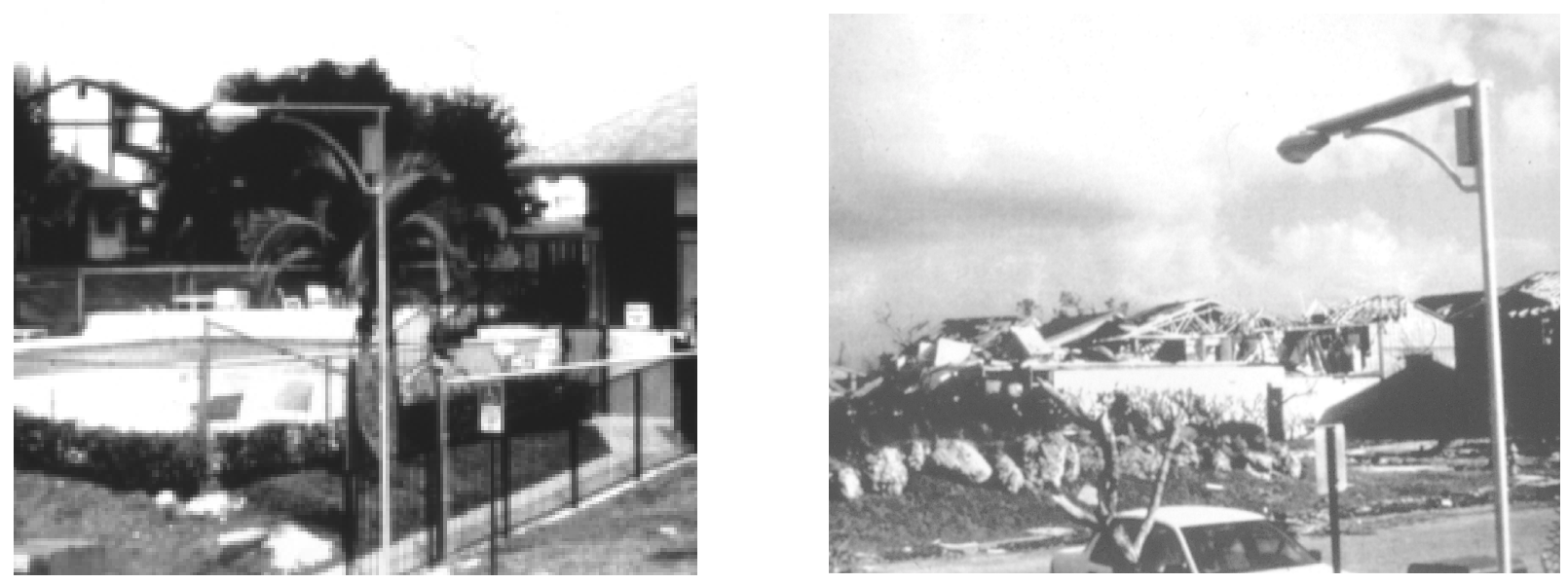

Figure 4. Before and after photos of a PV streetlight in Homestead, a suburb of Miami. Not only were the PV lights the only structures to survive Hurricane Andrew, but they provided the only electricity for several weeks (photos courtesy of Solar Outdoor Lighting, Inc.).

23 "Solar Home Weathers the Storm," Solar Today, Industry News, November/December 1996, pg. 34.

24 “PV in Paradise," Solar Today, November/December 1998, pp. 26-29. 


\section{Aftermath - Power from the Sun}

Electricity is crucial to nearly every aspect of rescue operations, e.g., security, communications, medical services, pumping of fuel, and water purification. PV's well-known characteristics of mobility, ruggedness, reliability and grid-independence, which make it so useful in other situations, are even more valuable after a disaster (Figures 5 and 6).

As far as is known, the first deliberate use of PV as a emergency management tool was during Hurricane Hugo in 1989. A Florida distributor, 12 Volt Catalog, assembled and distributed systems to disaster shelters, medical clinics, and emergency management offices. Three years later, when Hurricane Andrew struck Miami suburbs in 1992, the Photovoltaic Design Assistance Center at Sandia National Laboratories provided funding for staff of the Florida Solar Energy Center (FSEC) to use PV to power a medical clinic and other applications. ${ }^{25}$

Since then, PV has been used in a wide variety of emergency management situations. Several companies now make trailer-mounted, PV-powered generator sets ("gensets") up to about two kilowatts. The energy from PV systems,

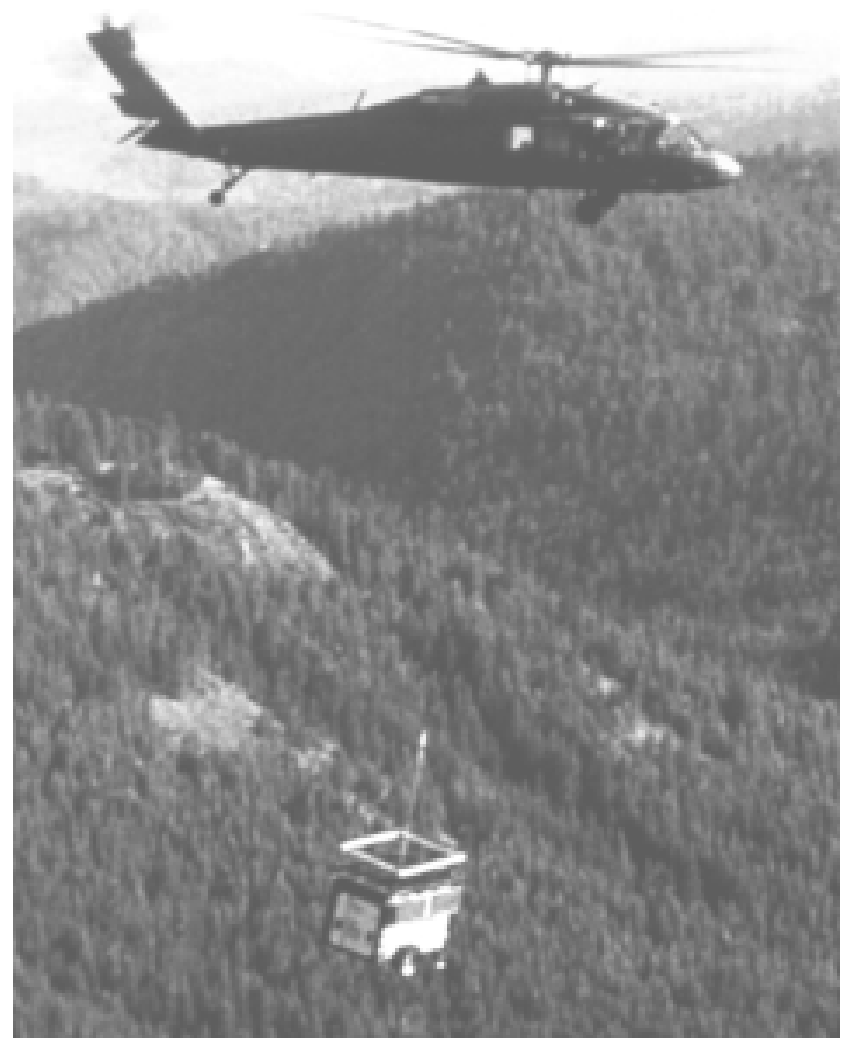

Figure 5. A portable PV genset is helicoptered into the mountains of California (photo courtesy of Live Oak Solar). which can either be pulled by a vehicle or airlifted, can be used immediately or stored in batteries for later use. Some of the gensets even carry a backup propane generator for use in prolonged cloudy weather. A wide variety of PV-powered lights, portable communication systems, and compact, lightweight power supplies capable of recharging the batteries of a laptop computer or cellular phone and other equipment are commercially available.

\section{Solar Technologies - Added Value to Consumer and Insurer Alike}

Solar technologies and energy-efficient buildings are not just for use during emergencies. They contribute steadily throughout the year, bringing extra value to their owners. They save money, reduce dependence on fossil fuels, and improve air quality. Although the extent of the medical benefits of living in daylighted homes with proper air circulation are still being argued, they do exist and result in a healthier population.

${ }^{25}$ Young, Jr., William R., "Real-Life Applications of Photovoltaic Power to Hurricane Andrew Relief," FSEC-PF-284, Florida Solar Energy Center, Cocoa, FL, 1994. 
PV gensets, traffic control units, mobile communication trailers, and other equipment can all be used to support tourism and community functions. The integration of larger-scale PV into utility systems has also been shown to increase reliability. ${ }^{26}$

\section{Next Steps}

The most effective response to reducing the impact and cost of natural disasters in the future is to develop a partnership among insurance companies, utilities, state and federal agencies, DOE's national laboratories, and the renewable industry to encourage the use of PV and other renewables. Energy efficiency and passive solar should be encouraged as ways to increase building resilience and to decrease energy dependence.

The problem is not an impossible one. All of the prospective partners already have some experience with renewables. Insurance companies like Allstate and Travelers P\&C are leading the industry in the technological evolution. ${ }^{27}$ Allstate is the first insurer to dispatch claims over the Internet through its catastrophe (CAT) vans. Adjusters communicating to their CAT center in Chicago from the 37-foot CAT van recently settled more than 2,000 claims resulting from the Spring 1998 Florida forest fires. ${ }^{28}$ Travelers is developing client/server applications for its mobile unit to offer complete remote office-solutions and workflows through wireless and analog connection. Adjusters serviced claims for Atlanta and Nashville following recent tornadoes and for Florida fires using this mobile capability.

Many insurers, including the U.S.

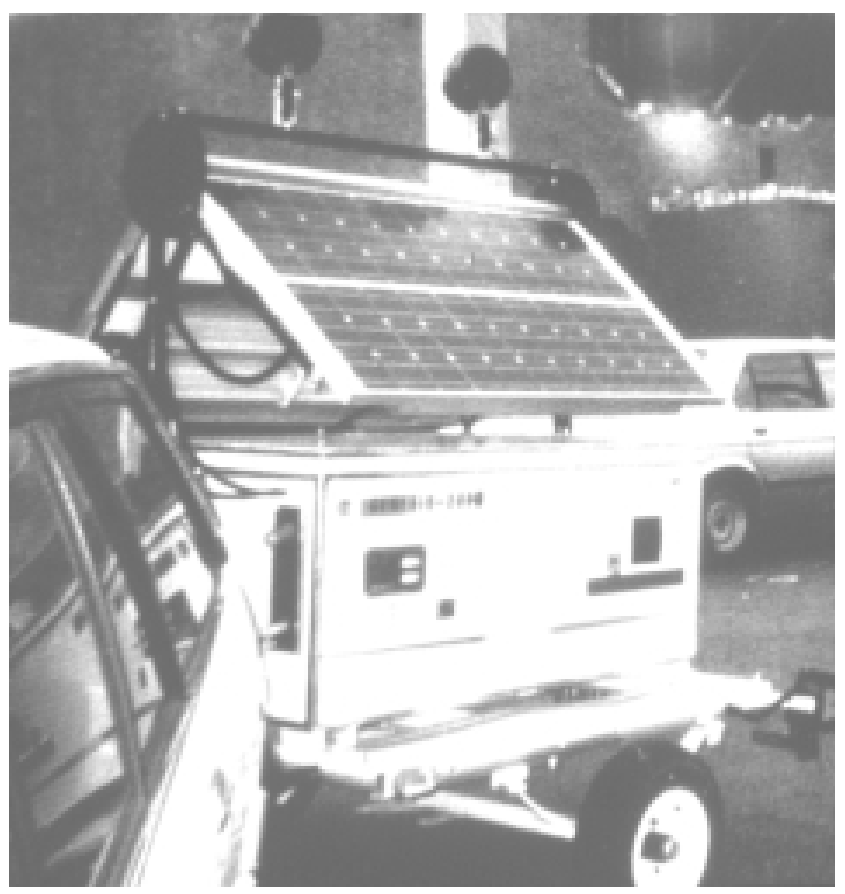

Figure 6. PV gensets come in a variety of sizes that produce up to several kilowatts. This mobile communications and lighting unit was used in the relief effort after the Los Angeles earthquake of 1991 (photo courtesy of Siemens Solar Industries). Automobile Association (USAA) and CNA, already distribute generators to insureds following disasters to reduce the cost of Additional Living Expense (ALE) coverage. By distributing PV generators instead of standard gas

26 Auerbach, Shimon, "Increasing Network Reliability Through the Integration of Photovoltaics and Uninterruptible Supply Systems: An Economic and Technical Evaluation of the Boston Region,” U.S. Department of Energy, Boston, 1995.

27 Mills, Evan, “Going Green Reduces Losses,” Reinsurance, March 1997.

28 “Coastal Exposures and Community Protection: Hurricane Andrew's Legacy," The Insurance Institute for Property Loss Reduction and the Insurance Research Council, April 1995. 
generators, these companies could provide their customers with safe, reliable, electrical generation systems to power lights, communications, fans, and other critical systems following a disaster. A residential PV system consisting of a rechargeable battery, lights, and a radio — with a detachable PV-mounted module and costing under \$500-would allow residents to stay safely in their homes. Vandalism would be reduced because residents and owners would be able to look after their own property.

Uninterruptible power supplies (UPS) are used in commercial buildings to protect critical applications such as computer networks and security systems in the event of a power failure. Roof-mounted PV systems can often augment existing UPS systems to power specific equipment. State-of-the-art PV systems can be expected to have lifetimes of 20 to 30 years, often making them economically viable alternatives.

The world's largest insurance company, Swiss Reinsurance Company (Swiss Re), recently invested \$2.75 million in SunLight Power International Holdings, a small company that intends to install one million PV systems in five countries during its first seven years. Swiss Re's investment followed closely on a similar \$2 million commitment by the European giant, Gerling Insurance Group. ${ }^{29}$

Utilities are also becoming aware of the potential of renewables. The Sacramento Municipal Utility District has one of best-known programs for installing PV on residences and other buildings. But other utilities are following closely behind with similar "green buying" programs. Many utilities are planning ahead to determine the most effective way to deal with the aftermath of a disaster. Direct Global Power, Inc., has proposed a program called RESTART (Reconstructive Solar Technology and Relief Task Force) to develop specific PV products to furnish the energy needs of residents and businesses following disasters. The company is working with insurers and utilities not only to design dual-use photovoltaic products that will furnish electricity to the utility system during normal conditions, but to have them pre-deployed in utility service areas throughout the United States as potential emergency response systems before disasters occur.

The Federal Emergency Management Agency (FEMA) and many state and local emergency response units have deployed PV systems in a small way. These agencies are open to using renewables, but only if renewables fit into established emergency plans and if their staffs are well-trained in the use of renewables.

There have been several attempts by FSEC, the North Carolina Solar Center, and NREL to volunteer the use of PV during disasters. These efforts have met with limited success due to the last-minute nature of the attempts. Experience has shown that the only way PV and other renewables will be used is if users are well-acquainted with the technologies and know how to apply them before the disaster occurs, and if they are included in transportation planning.

29 "Swiss Reinsurance Becomes Largest SunLight Power International Investor," The Solar Letter, Vol. 7 , No. 15, ALFA Publishing, Allan Frank Associates, July 18, 1997, p. 285. 
One finding of FSEC surveys and workshops with emergency managers is that there is a substantial lack of knowledge about the application of solar technology in times of disaster. Consumers are also unaware of the benefits of solar technology. Knowledge of these benefits may be brought into the mainstream by using the technical resources of DOE and utilities and the consumer distribution network of the insurance industry, which consists of both consumers and businesses.

Insurers at the June 22 meeting expressed interest in collaborating with NREL and utilities to develop educational programs for consumers and small businesses on the use, costs, and applications of solar technology in disaster mitigation and response. Insurers suggested that both printed and video products be developed and distributed. Solar technologies are new to the public, and a definite need exists to reach out to a broad consumer base. The acceptance of solar technology by the general public is important to insurers, because these people are their customers. Insurers could serve as one distribution channel in reaching their policyholders, informing them of this new emergency generator option in the event of a power disruption.

Field experience has also shown that better pre-disaster coordination needs to occur between insurers and emergency response organizations. Efforts that should reinforce each other often become roadblocks. NREL staff members have learned that the only way to achieve a smooth response is to work out the details beforehand. Once emergency operations have started, time for education and planning is simply not available.

As mentioned previously, the renewables industry is anxious to help. Improved PV products appear continuously. As these products are deployed, feedback will be needed from the emergency response sector to further improve these products.

The national laboratories are already involved with FEMA to transfer promising technologies from the laboratories to industry, the federal sector, and state organizations. ${ }^{30}$ DOE's Federal Energy Management Program (FEMP) and the Atlanta Regional Support Office (ASO) recently joined together to provide FEMA with solar gensets for training and for actual use during emergencies. These units are now being distributed to several FEMA regions. NREL staff are providing training to FEMA staff members; these efforts are aimed at avoiding past deployment problems during disasters. Even with these efforts, substantial resources within the national laboratories remain to be tapped. ${ }^{31}$

The insurance industry has expressed interest in several areas that need to be addressed. These areas include the public acceptance of PV systems, the willingness of the public utilities and government to form an effective partnership, methods for public outreach, and improved methodology for determining the value of PV to disaster prevention, response, and recovery. A

\footnotetext{
30 The FEMA committee is known as the "Emergency Management Technology Steering Group." ASO's director, Jim Powell, and one of the authors (John Thornton) are members of this committee.

${ }^{31}$ Vine, Edward; Evan Mills; and Allan Chen, Energy Efficiency and Renewable Energy Options for Risk Management and Insurance Loss Reduction: An Inventory of Technologies, Research Capabilities and Research Facilities at the U.S. Department of Energy's National Laboratories, LBNL-41432, Lawrence Berkeley National Laboratory, Berkeley, CA, August 1998.
} 
more detailed report of the insurance industry's specific interests and requests — and the extent to which answers are known-is being prepared by the authors. The report is expected to be published in January 1999.

The authors are also planning follow-on workshops to the June 1998 meeting. Key executives, planners, and visionaries from utilities, insurers, the solar industry, federal agencies, and state response organizations will be asked to create the framework of a plan for accelerating the use of renewables in disaster prevention and emergency response. This framework will address the types of equipment that are needed, training, deployment strategies, financing mechanisms, and how the plan should be presented to all partners and the public.

\section{Acknowledgements}

Support for this work was provided by the U.S. Department of Energy's National Photovoltaic Program, the Federal Energy Management Program, and the Denver Regional Support Office. John Eager, Director of Claims Services of the National Association of Independent Insurers, and James P. Romerill, Senior Vice President of American Modern Insurance Group, Inc., provided useful information and much appreciated encouragement. 


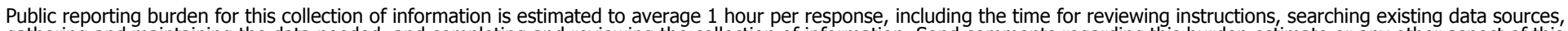

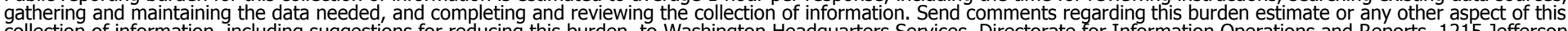

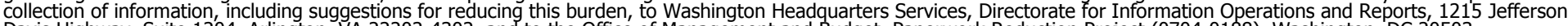

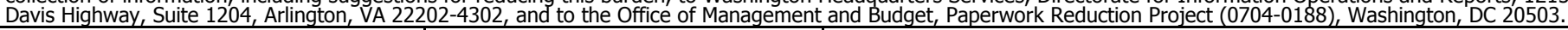

\begin{tabular}{|l|l|l} 
1. AGENCY USE ONLY (Leave blank) & $\begin{array}{l}\text { 2. REPORT DATE } \\
\text { April 1999 } \\
\text { Revised July 1999 }\end{array}$ & $\begin{array}{l}\text { 3. REPORT TYPE AND DATES COVERED } \\
\text { Research report }\end{array}$
\end{tabular}

4. TITLE AND SUBTITLE

Solar Technology and the Insurance Industry: Issues and Applications

6. AUTHOR(S)

A. Deering and J. P. Thornton

5. $\mathrm{C}$

TA: PV908101

8. PERFORMING ORGANIZATION REPORT NUMBER

National Renewable Energy Laboratory

1617 Cole Blvd.

Golden, CO 80401-3393

9. SPONSORING/MONITORING AGENCY NAME(S) AND ADDRESS(ES)
10. SPONSORING/MONITORING AGENCY REPORT NUMBER

TP-520-26490

\section{SUPPLEMENTARY NOTES}

12a. DISTRIBUTION/AVAILABILITY STATEMENT

National Technical Information Service

U.S. Department of Commerce

5285 Port Royal Road

Springfield, VA 22161 12b. DISTRIBUTION CODE

13. ABSTRACT (Maximum 200 words)

Today's insurance industry strongly emphasizes developing cost-effective hazard mitigation programs, increasing and retaining commercial and residential customers through better service, educating customers on their exposure and vulnerabilities to natural disasters, collaborating with government agencies and emergency management organizations, and exploring the use of new technologies to reduce the financial impact of disasters. Solar technology can be used in underwriting, claims, catastrophe response, loss control, and risk management. This report will address the above issues, with an emphasis on pre-disaster planning and mitigation alternatives. It will also discuss how energy efficiency and renewable technologies can contribute to reducing insurance losses and offer suggestions on how to collaborate with the utility industry and how to develop educational programs for business and consumers.
14. SUBJECT TERMS
photovoltaics ; pre-disaster planning ; catastrophe response ; claims management ; loss control ; risk management OF REPORT Unclassified
17. SECURITY CLASSIFICATION
18. SECURITY CLASSIFICATION OF THIS PAGE Unclassified
19. SECURITY CLASSIFICATION OF ABSTRACT Unclassified

15. NUMBER OF PAGES 21

16. PRICE CODE

Standard Form 298 (Rev. 2-89) Prescribed by ANSI Std. Z39-18

NSN 7540-01-280-5500 